УДК 929:80 Даничић Ђ. 811.163.41:811.135.1

https://doi.org/10.18485/msc50.2021.2.ch24

\author{
Георге Михаила
}

\title{
ДОПРИНОС ЂУРЕ ДАНИЧИЋА СЛОВЕНСКО-РУМУНСКОЈ ФИЛОЛОГИЈИ
}

Научна делатност великог српскохрватског филолога Ђуре Даничића (1825-1882), тако богата и разноврсна да лежи - уз ону коју је објавио Вук Стеф. Караџић - у основи више области југословенске филологије, није остала без благодетних последица по словенско-румунску филологију. Он је, по лапидарном карактеризовању његовог млађег пријатеља В. Јагића, био „верным приверженцем идей Вука и представителем научного направления Миклошича по сербскому языку и по славянской филологии... Примкнув с полным убеждением и знанием дела к идеям Вука, он приобрел в сочинениях Миклошича и дружбе с ним острое оружие в пользу нового направления, при помощи которого можно было разумно вести дело Вуково дальше".

Баш зато, једно од његових интересовања, још из првих година његове научне делатности, које је отпочео у својој двадесетој години, било је популаризовање радова његовог учитеља и старијег пријатеља; и то како оних који су се непосредно односили на питања српскохрватског језика и српскохрватске филологије, тако и оних који су се тицали ширих области славистике и односа словенских језика са суседним језицима; био је то правац у коме се Миклошич јавио правим крчитељем нових путева.

1 История славянской филологии (Энциклопедия славянской филологии, вып. 1), СПб., 1910, стр. 737 (параграф посвећен Даничићу, стр. 737-745; фотомеханичка репродукција: Leipzig, Zentralantiquariat der DDR, 1967); види и: Прослава стогодишнище од рођења Ђуре Даничића. Свечани скуп Српске Краљевске Академије, 18. октобра 1925 год., Српска Краљевска Академија, Годишюак, XXXI, 1925, Београд-Земун, 1926, стр. 121-234, нарочито: А. Белић, Бура Даничић. 6. I. 1825 - 5. XI. 1882, стр. 151-202; Т. Маретић, Книжевни рад Даничићев у Југославенској академији, стр. 203-234; А. Белић, Буро Даничић, ЈФ, V, 1926, стр. 1-26; Ђорђе Живановић, Млади Даничић, Зборник Матиие српске за книжевност и језик, књ. 1, 1954, стр. 101-122; књ. 2, 1955, стр. 108-122; књ. III, 1955, стр. 126-135. 
Тако, међу његовим првим рецензијама о радовима великог словеначког слависте убраја се и извештај о студији Die Sprache der Bulgaren in Siebenbürgen ${ }^{2}$, објављен у Српским новинама бр. 10 од 22. јан. $1857^{3}$, у времену када је био библиотекар и секретар Друштва србске словесности. Представљајући Миклошичеву студију и текст Бугарског канциионала из 1830, откривеног у Чергаул-Мик (Мали Чергед) у околини Блажа, Даничић задржава његов закључак да се ради о архаичном језику бугарских колониста који су - како је касније установљено - дошли у Трансилванију негде у XIII веку и који су у XVI веку прешли у протестантизам. За илустрирање, рецензент репродукује одломак текста, транскрибујући српском азбуком рукопис, који је Миклошич објавио латиницом, а местимично га пропраћајући објашњењима о појединим речима, писаним у заградама: „(II) ... Што ие веара-тар? Веара-ти иест бизуита (истинска, чему још треба додати: надеша), на божа башта свента милла итд.” ${ }^{4}$

У вези са овом насеобином - као и у вези са друге две - у Трансилванији (Русчори и Бунград, близу Сибиња) - треба напоменути да је она била румунизирана већ почетком XIX столећа, као последица интензивног и дугорочног контакта са преовлађујућим румунским становништвом, мада је била прешла на лутеранизам и налазила се под немачким утицајем, а службени је језик био мађарски. Једини трагови бугарског језика чували су се прошлог столећа у два преписа Cantionale seu Graduale bulgaricum (jeдан, старији од оног који је Миклошич штампао, датиран 1812, који садржи, као и овај, много румунизама, објавио је Л. Милетић 1896). ${ }^{5}$

Четири године касније, када је већ био професор Велике школе у Београду, непосредно после појаве опширне студије Фр. Миклошича, Die slavischen Elemente im Rumunischen ${ }^{6}$, која је положила темеље научног проучавања словенско-румунских односа ${ }^{7}$, Ђура Даничић објављује

${ }^{2}$ Сепарат из Denkschriften der kaiserlichen Akademie der Wissenschaften, Philosophisch-historische Classe, II. Band, Wien, 1856.

3 Прештампано у: Ситнији списи Ђ. Даничића I, Ср. Карловци, 1925, стр. 199-201.

4 Види читав одломак прештампан у наведеном делу, стр. 200-201.

5 Види Л. Милетич, Седмиградските българи, СбНУ, књ. XIII, 1896, стр. 153 256 (са библиографијом) и друге чланке истог аутора; Ion Mușlea, Șcheii de la Cergău și falclorul lor, Dacoromania, V, 1927-1928, стр. 1-50 (са библиографијом); К. Мирчев, Бележки върку грбиките заемки въ езика на седмоградските българи, „Известия на Института за български език”, I, 1952, стр. 231-238.

${ }^{6}$ Сепарат из Denkschriften..., Phil.-hist. CL., XII. Bd., Wien, 1861.

7 Види Ioan Bogdan, Franz Miklosich, y: Scrieri alese, București, 1968, стр. 584-589, G. Mihăilă, Studii de lexicologie și istorie a slavisticii romănești, București, 1973, cтр. 170-172. 
у новинама Видов дан, чији је уредник био његов брат Милош Поповић (бр. 71 од 16. септембра 1861), нову рецензију. ${ }^{8}$ Он придаје посебну пажњу историјском делу, у коме „доказује Миклошич да је румунски језик почео постојати у почетку II века, кад се већина Римљана населила на левој обали доњега Дунава; то доказује језиком румунским налазећи у њему не само много класичних речи из времена Августа него и многе друге ствари из латинскога језика у старијој форми него што су у језику италијанском и француском". 9 У наставку он резимира идеје бечког слависте о аутохтоним, трачко-дачким елементима румунског језика, о такозваним „балканизмима”, и најзад, о словенском утицају на творбу речи и, нарочито, на речнички састав румунског језика.

Без сумње, од тада је проучавање словенско-румунских језичких односа знатно напредовало, како у односу на словенске позајмице у румунском језику тако и обратно - у односу на румунске позајмице у суседним словенским језицима. У вези с тим треба подвући да још од краја прошлог столећа и првих деценија нашега века румунски етимолози - J. Богдан (I. Bogdan), X. Тиктин (H. Tiktin), onda C. Пушкарју (S. Pușcariu) и његови сарадници, J.-A. Кандреа (I.-A. Candrea), Е. Петровић (E. Petrovici), A. Росети (A. Rosetti) и други - широко су употребљавали како Рјечник из кюижевних старина српских (3 тома, Београд, 18631864), тако и свеске Rječnika hrvatskoga ili srpskoga jezika, чију је обраду и објављивање отпочео Ђура Даничић 1880. год. у Загребу, на основу грађе коју је Југославенска академија знаности и умјетности сакупљала још од 1867. (Како је познато, штампање Rječnika приближава се крају).

Први - „превосходный словарь, составленный на основании древне-сербской письменности и грамот", штампан пре више од сто година, паралелно са Миклошичевим Lexiconom (Lexicon palaeoslovenicograeco-latinum, Vindobonae, 1862-1865) и три деценије пре Материјала Срезњевског (Матеріалы для словаря древнерусскаго языка, 3 тома + Дополнение, СПб., 1893-1912) - до данас чува своју вредност, будући - по речима В. Јагића - „самым капитальным трудом этих годов” ${ }^{10}$ Два аспекта нас интересују у вези с овим речником:

1) Поред Миклошичевог Lexicona и Mатеријала Срезњевског (којима се сада додаје Словарь русского языка XI-XVII вв., вып. 1 (А-Б), Мо-

8 Прештампано у: Ситнији списи Ђ. Даничића, стр. 170-172.

9 Исто, стр. 264.

${ }_{10}$ История славянской билологии, стр. 741. Види, у последње време: Радован Загорић, Са маргина Даничићева рјечника, ЈФ, књ. XXVII, 1966-1967, св. 1-2, стр. 357-364, где се даје неколико допуна код значења појединих речи. 
сква, изд. Наука, 1975, главний ред. С. Г. Бархударов), Рјечник је изврстан инструмент рада на проучавању књижевно-словенских позајмица у старом румунском књижевном језику, од којих неке са фонетским цртама или семантичким специфичним нијансама српске рецензије. Ево неколико примера:

Crug < српско-књижевносл. КРОУГЬ (Рјечник, I 494; уп. и руско-књижевносл. кругъ), поред crîng < ст. сл. крхгъ.

Мисепіс < српско-књижевносл. МОУЧЕНИКЬ (Рјечник II 98; уп. и руско-књижевносл. ивтеннкъ), поред тӑсепі́с (средњобуг. мхчєннкъ = мъченнкъ); исто: muсе́nie (< мо8тєннгє) и тисепі́ţă (< мо8чєннца).

Odór „вредан предмет” < српско-књижевносл. ОДОРЬ (истина, забележено само у Rječniku hrvatskoga ili srpskoga jezika III, 648: òdor „pohara, razboj; plijen; imovina, svojina”).

Ро́рӑ < српско-књижевносл. ПОПО (ПОПО ЖИВКО, Рјечник, II 356; срп. диал. ро́ро, рópa, Rječnik, X, 777, 805).

Rucaviță < српско-књижевносл. РОУКАВИЦА (бележено, истина, у Миклошичевом Lexiconu, 815; рхкавнцц, и у Rječniku XI, 288: rukàvica; у књижевносл. румунске рецензије: РУКАВИЦА). ${ }^{11}$

2) Рјечник је први сакупио неколико властитих имена и речи румунског порекла Влаха средњовековне Србије, забележених у споменицима. А ово - како су већ Б. П. Хашдеу и Ј. Богдан крајем прошлог века подвукли, и како се недавно опет истицало ${ }^{12}-$ убраја се међу најстарије писане примере румунског језика. Ево неколико примера које је Даничић црпао из старих српских споменика:

Baci: „БАЧЬ, једноме влаху којега је краљ Милутин дао Хиландару бјеше тако име. М. 59" (Рјечник I, 30).

Búcur: „БОУКОУРЬ, име влаху у Хвосну којега краљ Милутин даде Хиландару. М. 61” (I, 87).

Bun: „БОУНЬ, тројици влаха које је краљ Стефан Првовјенчани дао Жичи тако је било име. М. 1213” (I, 89).

Mic: „МИКЬ, између Влаха које је краљ Стефан Првовјенчани дао Жичи једном бјеше име МИКЬ. М. 12" (II, 62).

11 Види Lucia Djamo-Diaconiță, у књизи: Р. Olteanu и кол., Limba slavă veche, şi slavona românescă, Bucuresti, 1975, стр. 266.

12 Види В. Р. Hasdeu, Arhiva istorică a României, III, 1867, стр. 85-196; I. Bogdan, Scrieri alese, стр. 159-164; S. Dragomir, Vlahii din nordul Peninsulei Balcanice in Evul Mediu, Bucureşti, 1959; G. Mihăilă, Dicționar al limbii române vechi, Bucureşti, 1974. 
Oparitul: „ОПАРИТОУЛЬ, име мушко: између људи које цар Стефан даде цркви арханђеловој у Призрену једном бјеше име ОПАРИТОУЛЬ. Г. ХV. 295” (II, 220).

Singur: „СИНЬГОУРЬ, име мушко, између људи које краљ Стефан Првовјенчани даде Жичи једном бјеше тако име. М. 13” (III, 112).

Súrdul: „СОУРЬДОУЛЬ, име мушко: између људи које цар Стефан даде цркви арханђеловој у Призрену једном бјеше име СОУРДОЛЬ. Г. ХV. 270" (III, 204).

Úrsul-: „ОУРЬСОУЛОВИЋЬ, између људи које цар Стефан писа цркви арханђеловој у Призрену један бејеше БОГДЕ ОУРЬСОУЛОВИКЬ. Г. ХV. 289" (III, 380).

Feciór: „ФЕЧОРЬ, између људи које цар Стефан писа цркви арханеђловој у Призрену један бјеше МАРКО ФЕЧОРЬ. Г. ХV, 272" (III, 403).

Што се тиче Rječnika hrvatskoga ili srpskoga jezika - или „Даничићева речника", како је још називан ${ }^{13}$, од којег је Даничић успео да објави само први том и да обради део другог тома - овај импозантан историјски речник био је коришћен, а коришћен је и данас, од румунских лингвиста у вези са три аспекта словенско-румунских (посебно српско-хрватско-румунских) језичких односа, захваљујући његовом ванредном богатству књижевних и народних, дијалекатских речи, бележених до XIX-ог столећа: ${ }^{14}$

1) Проучавање српскохрватских позајмица у румунском језику, тачније у говорима Баната и суседних жупанија Олтеније, југозападне Трансилваније и Кришане, могло је да напредује последњих деценија захваљујући радовима Емила Петровића, Раду Флоре, Т. Трпче, Д. Гамулескуа и других, баш захваљујући, у првом реду, овом богатом Rječniku, у

${ }_{13}$ Види П. К. Булат, Даничић у светлу Академског Rječnika. Даничићев зборник, Београд-Љубљана, 1925, стр. 288-294.

${ }_{14}$ Осим старијих речника Вука Караџића, Ф. Ивековића и И. Броза и др., сада му треба додати два велика речника у току обраде и издавања: Речник срискохрватског кюижевног и народног језика, који издаје Српска академија наука и уметности - Институт за српскохрватски језик (књ. I-VIII, A-J, Београд, 1959-1973) и Речник српскохрватскога книжевног језика, који издају Матица српска и Матица хрватска (књ. I-V, А-С, Нови Сад - Загреб, 1967-1973; паралелно се штампа и хрватска варијанта), као и драгоцен Etimologijski rječnik hrvatskoga ili srpskoga jezika, који је остао од Петра Скока у рукопису и који су припремили за штампу М. Деановић, Љ. Јонке и В. Путанец (књ. I-III, Zagreb, 1971-1974); уп. и: Josip Matesić, Rückläufiges Wörterbuch der Serbokroatischen, Bd. 1, Lief. 1-4, Wiesbaden, 1965-1967. 
којем су регистровани бројни дијалектизми, непознати стандардном књижевном језику, али присутни у суседним румунским говорима. Тако, у недавном свом раду Elementele de origine sîrbocroată ale vocabularului dacoromân - Elementi srpsko-hrvatskog porekla u dakorumunskom rečniku (Bucureşti - Панчево, 1974), Д. Гамулеску (D. Gămulescu), ослањајући се већином на податке Rječnika, установио је етимологију преко 700 румунских речи српскохрватског порекла, већина употребљених у Банату и суседним жупанијама, а неколико и у заједничком књижевном језику, као што су cîrd, cócină, dóniță, drug, drúgă, gîrlíci, otíc, păstrúgă, pléter, răcílă, şlíboviță и др. ${ }^{15}$

Наравно, истраживања се настављају и даља обрада великог Речника румунског језика (Dicționarul limbii române) у оквиру Румунске академије, најпре под руководством С. Пушкарјуа, а сада J. Јордана, Ал. Граура и J. Котеануа, скоро паралелно са загребачким Rječnikom (t. I-IX, Bucureşti, 1913-1975), изнеће нове позајмице из српскохрватског. Примера ради, DLR, II, 1, стр. 407, бележи регионализам nieredbă - неправилан став, злоба, употребљен у Банату и позајмљен из суседних српских говора: нередба, која међутим није забележена, јер ево шта се каже у Rječniku, VIII, стр. 58, под речи neredben: „Isto sto neredan, adj. („onaj, koji je u neredu; neuredan; besputan; adv. nemio"). Izvedeno od osnove imenice neredba, kojoj se nije našlo potvrde". ${ }^{16}$

2) Испитивачи старих словенских позајмица у румунском језику такође налазе у Rječniku, као и у другим српскохрватским речницима, врло драгоцен материјал, како у вези са словенским лексемама и њиховом територијалном расподелом, тако и у вези с њиховим семантичким развојем, будући да овај материјал има много заједничких црта у јужнословенским језицима. С пуним правом је пре неколико година скренуо пажњу на ово питање Н. И. Толстој: „Не излишне при этом иметь в виду уже достаточно утвердившееся в науке мнение о значительной древности отдельных лексических изоглосс и считаться с фактом несовпадения лексических и фонетических изоглосс ... Гипотеза центрального балканского клина и латеральных поясов, выдвинутая еще Копитаром и Миклошичем и недавно вновь возрожденная Б. Братаничем, не может быть разрешена без славянского материала, сохраненного румунским языком" (уп. рум. grindéi, plaz, potíng, răzbói, opíncă, и њихове кореспонденте у јужнословенским језицима). ${ }^{17}$

${ }_{15}$ Цит. дело, стр. 226. Оцена је основана на Dicționarul limbii române moderne, sub direcția lui D. Macrea, Bucureşti, 1958.

${ }_{16}$ Види G. Mihăilă, Studii..., стр. 94.

${ }_{17}$ Рец. на: G. Mihăilă, Imprumuturi vechi sud-slave în limba română, Bucureşti, 1960, у: Этимология, Москва, 1963, стр. 280-281. 
3) Најзад, нарочито последњих година, интензивирало се истраживање речи румунског порекла у североисточним српским говорима, засновано посебно на два речника загребачке Југославенске академије, београдске Српске академије, као и на дијалекатским збиркама и дијалекатским испитивањима. Од прилога штампаних у Румунији, посебно истичемо оне које су објавили Д. Гамулеску ${ }^{18}$ и Елена Михаила-Скарлатоју. ${ }^{19}$ Да се не бисмо упуштали у библиографске податке, биће довољно да подсетимо овде на Etimologijski rječnik Петра Скока.

Ђура Даничић је такође дао један од најважнијих доприноса на издавању и проучавању основних дела старе српске књижевности, која су била у оптицају и у Румунији. Он сам и каснији истраживачи употребљавали су не једном у својим издањима словенско-румунске рукописе, па некад и оне најстарије. Слободни смо да се укратко осврнемо и на тај аспекат.

Тако, најзначајније његово издање је Живот кралева и архиепископа српских. Написао архиепископ Данило и други (Загреб, 1866). Ово дело је врло значајно не само за историју старе српске књижевности него и за српскохрватско-румунске књижевне односе у средњем веку. ${ }^{20}$ Заиста, од пет данас познатих рукописа два су преписана на територији Румуније, у Молдавији.

Сам Даничић, узимајући као основу рукопис писан на рускословенском језику у манастиру Хиландару 1763 , дао је и варијанте и неке допуне не само према другом препису истог порекла из 1780, него и по једном много старијем, писаном у XVI веку у Молдавији, како је могуће судити по чињеници што га је 1570. купио ђак Глигорије Јурашко и дао на дар

${ }^{18}$ Ink̂kprumuturi româneşti şi aromaneşt în argourile sud-slave, „Studii şi cercetăr lingv."; XVI, 1965, 4, стр. 531-540; Etimologii sîrbocroate, ibidem, XXII, 1971, 5, стр. 525-530; Note de etimologie sîrbocroată, ibidem, XXIII, 1972, 1, стр. 69-74; Silvia Nița-Armaş, D. Gămulescu и други, L'influence romaine sur le lexique des langues slaves, „Romanoslavica”, XVI, 1968, стр. 59-121.

${ }^{19}$ Emprunts rounains dans le lexique serbocroate, „Revue des études sud-est européennes”, X, 1972, 1, стр. 95-113; XI, 1973, стр. 327-352.

20 Види Никола Радојчић, Животописачки рад архиепископа Данила и юегових настављача (1935), у књизи Стара книжевност. Приредио Ђ. Трифуновић, Београд, 1972, стр. 411-428; Ђ. Сп. Радојичић, Твории и дела старе српске кюижевности, Титоград, 1963, стр. 113-122; М. Кашанин, Српска книжевност y среднем веку, Београд, 1975, стр. 210-251; Ion-Radu Mircea, „Les vies des rois et archevêques serbes" et leur circulation en Moldavie. Une copie inconnues de 1567, RÉSEE, I, 1966, 3-4, стр. 393-412; G. Mihăilă, Contribuții la istoria culturii şi literaturii române vechi, Bucureşti, 1972, стр. 117-119. 
манастиру Сучевици. Репродукујући записе овог рукописа (стр. VI-VII), Даничић га карактерише овако: „Ти записи у лавовском рукопису ${ }^{21}$ свједоче да је он био године 1575, али писмо и правопис самога рукописа свједоче да он постао није много прије: јамачно је писан тек XVI вијека, а на хартији је писан. Језик у њему није какав је у тијем записима, него како су Срби писали у оно вријеме, али не са свијем чист" (стр. VII).

Значај овога рукописа, архаичнијег и сажетијег од друга два српска рукописа из XVIII века и који доказује старију етапу наставка овог биографског „корпуса”, поново је пре неколико година истакао румунски истраживач Јон-Раду Мирча, који је истовремено обелоданио и други молдавски рукопис, преписан од стране познатог летописца калуђера Азарија 1567. и данас сачуван у манастиру Сучевици (бр. 17/420). Значај овог преписа је како у његовој старини - данас је једини из XVI века који се још чува, јер је пети рукопис, Хиландарски из 1553, нестао на почетку $\mathrm{XX}$ века $^{22}$ - тако и по томе што он представља покушај прилагођавања - како Јон-Раду Мирча каже - „à la langue littéraire propre aux écritures et aux Lettrés moldaves: le slavon ecclésiastique de rédaction médio-bulgare, avec des éléments propres aux Pays Roumains". ${ }^{23}$

Дакле, два молдавска преписа доказују оптицај овог дела у црквеним и књишким срединама у нашој земљи, јер су читана, можда, чак и од неких молдавских владара: препис Глигорија Јурашка могао би водити порекло из епохе Петра Рареша (1527-1538, 1541-1546), ожењеног Јеленом Бранковић, а препис Азарија датира из времена владавине Александра Лапушнеануа, чија је супруга Росанда била кћи Рареша и Јелене. ${ }^{24}$ Штавише, преко Азарија, аутора последњег молдавског рукописа на књижевнословенском, писан нешто касније, 1574-1575, Данилов зборник надовезује се на румунску средњовековну историографију и дозвољава нам да са већом прецизношћу оцртамо делатност овог калуђера-књижевника.

Најзад, последњи јужнословенски средњовековни напис који представља интерес за словенско-румунске културне односе и који је Ђура Даничић делимично издао и опширно коментарисао је Knjiga Konstantina filosofa o pravopisu (Starine I, 1869, стр. 1-43). Проучавајући и објављујући

${ }^{21}$ У ово време се рукопис чувао у Универзитетској библиотеци у Лавову; нестао је за време Другог светског рата.

${ }_{22}^{22}$ Види Ђ. Сп. Радојичић, Старе српске повелье и рукописне књиге у Хиландару, Архивист II, Београд, 1952, стр. 74, Ion-Radu Mircea, uзит. дело, стр. 339.

${ }_{23}$ Цит. дело, стр. 403.

${ }^{24}$ Види детаље код Ion-Radu Mircea, Relations culturelles roumano-serbes aux XVIième siècle, RÈSEE 1, 1963, 3-4, стр. 391-395. 
опширне изводе из овог врло интересантног лингвистичког дела (1418) четврт века пре потпуног издања В. Јагића ${ }^{25}$, Даничић репродукује (стр. 11) као одломак у коме Константин „говори да су се књижевне поуке трновског патријарха Евтимија, његовог учитеља, распространиле биле чак и по скитским земљама - << И ВЪ СКИЮСКЫХЬ СТРАНАХЬ >>, то јест у Русији и у Румунији"26, тако и правило о писању и о изговору слова Ђ, са једним примером из румунског језика (на стр. 18): „... али и глас тому слову рад Константин показати, и да би га показао тражи помоћи у турском језику и у новогрчком и у влашком”: „... нлн влашкын(м) єъыко(м) како право рє(ч)шн вь (= bea „пити)”; с ь Бо и сє, а нє сє”. ${ }^{27}$

Такође Ђура Даничић обраћа пажњу да се у завршном делу „врдничког” (1704) и „другог биоградског” рукописа (Народна библиотека, бр. 114) истиче „да је број словима 40 и да су у том броју два „бугарска” слова и два „влашка”, од којих је једно и” (стр. 42). ${ }^{28}$

Осим тога подсећамо да је кратка варијанта овога написа, Gїа словєса въ кратц' ндвранна шт кннгы Константнна фнлософа, поред српских преписа од којих је сам Даничић навео три - и руских преписа, сачувана у четири словенско-румунска преписа из XVI века, од којих је Јагић користио два у свом издању. ${ }^{29}$

Према томе, Ђура Даничић - лингвиста и филолог у ширем смислу речи, један од оснивача модерне српскохрватске лингвистике и филологије, поред и одмах после Вука Караџића - учинио је знатан допринос и у словенско-румунској филологији, како сопственим радовима тако и перспективама које су ови радови отворили. ${ }^{30}$ Савременик Б. П. Хашде-

${ }_{25}$ Рассуждения южноставянской и русской старины о иерковно-славянском языке, у: Исследования по русскому языку, СПб., 1885-1895, стр. 366-581 (фототипска репродукција: München, Wilhelm Fink Verlag, 1968).

${ }^{26}$ И. Барбулеску, О значају румунске филологије за проучаване српског језика и кюижевности, сепарат из СХХІ књ. „Гласа Српске Краљевске Академије”, Београд, 1926, стр. 93-94.

27 Види В. Ягич, изит. дело, стр. 403, 493-494; Ilie Bărbulescu, Fonetica alfabetului cirilic în textele române din veacul XVI şi XVII, Bucureşti, 1904, cтр. 130-131; G. Mihăilă, Contribuții..., стр. 45.

${ }_{28}$ Види и: В. Ягич, изит. дело, стр. 969 (рук. бр. 267 Народне библиотеке у

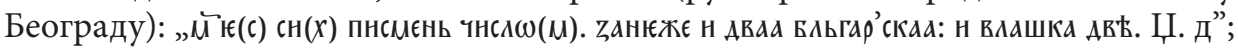
Т. Маретић, иит. дело, стр. 216.

29 Види Е. Turdeanu, La littérature bulgare et sa diffusion dans les Pays Rounains, Paris, 1947, стр. 158; G. Mihăilă, uит. дело, стр. 43-44.

${ }^{30}$ Мада се овде не бавимо његовим капиталним радовима у области српскохрватске акцентологије (прештампани у књизи: Ђуро Даничић, Српски акценти, Београд-Земун, 1925), ипак желимо да подсетимо овде на једно од пр- 
уа, Ал. Чихака, Ал. Одобескуа, Ђ. Даничић се убраја међу оне словенске филологе који, поред Миклошича, могу бити сматрани за иницијаторе словенско-румунских студија, како у области лингвистике тако и у области старе књижевности. Његово научно наследство урађа плодом, мада је прошло више од једног столећа од његовог штампања.

Георг Михаила

ВКЛАД ДЖУРО ДАНИЧИЧА В РАЗВИТИЕ СЛАВЯНО-РУМЫНСКОЙ ФИЛОЛОГИИ

Резюме

Научная деятельность выдающегося сербохорватского филолога Джуро Даничича (1825-1882) настолько богата и разнообразна, что наравне с научной деятельностью Вука Караджича легла в основу нескольких направлений югославской филологии, а это благоприятно отразилось и на развитие славяно-румынской филологии. Кроме целого ряда небольших статей какими являются рецензии о научных трудах Франца Миклошича, посвященные славяно-румынским проблемам, имеются и крупные его труды из которых три имеют прямое значение для славяно-румынских научных исследований: Рјечник из книжевних старина српских (3 тома, Белград, 1863-1864), издание Живот кратева и архиепископа српских. Написао архиепископ Данило и други (Загреб, 1866) и большой Рјечник хрватскога или српскога језика, над которым в 1880 г. начал работать Даничич, а продолжили до наших дней его сотрудники и ученики.

И действительно, исследование как славяно-румынской редакции и рукописей сербской редакции, переписываемых на Румынской Земле с XV по XVII вв, так и некоторых сербохорватских заимствований в древнерумынском литературном языке, немыслимо без широкого использования вышеприведенного словаря. С другой стороны Даничич лично опубликовал труд по сербской историографии, пользуясь тремя рукописями из которых одна была переписана в Молдании еще до 1574 г. (Львовская рукопись); как свидетельство широких сербско-румынских литературных связей за-

вих експерименталних истраживања које припада румунском слависти Јосипу Поповићу (Iosif Popovici), Sur l'accent “ en serbocroate (Extrait de „La parole”, no 5, Mai 1902, 12 р.), и које изгледа није познато садашњим југословенским специјалистима (уп. а. Пецо и П. Правица, О природи акцената српскохрватског језика на основу експерименталних истраживана, ЈФ XXIX, 1972, 1-2, стр. 195-242). 
служивает внимания румынская копия, сделанная известным молдавским хроникером Азарием в 1567 г., которую для научного мира открыл Йон Раду Мирцеа в 1966 г. Словом, во всех славяно-румынских и особенно в сербохорватско-румынских этимологических исследованиях, с 1880 года по сегодняшний день был использован богатый, с точки зрения аттестации слов в текстах и говорах и их семантики, лексический материал.

Реферат с верхним заглавием ставит себе задачей расскрыть эти аспекты. 